\title{
Documentation at the Ethnographic Museum in Zagreb
}

The paper provides a concise overview of documentation management activity performed at the Ethnographic Museum in Zagreb during the period ranging from 1919 to this day. It strives to highlight the importance, as well as the changes and the expansion of the role of documentation management in museums over time. The continuity of documentation management at the Ethnographic Museum has been pointed out over the first 100 years of its activity and the work of the people who have played a crucial role in the formation and the documentation management at the Museum has been concisely presented. The conclusion presents the current challenges and efforts to harmonise the documentation management tradition with the changes in laws, technological development and international standards.

Key words: Ethnographic Museum (Zagreb)

museum documentation, museum holdings, material inventory

\section{INTRODUCTION}

The management of documentation of museum objects at the Ethnographic Museum started immediately upon the foundation of the museum in 1919. The formation of a body of records referred to as documentation holdings ensued, which provided quality grounds for museum documentation and records management that has been upgraded to date.

In this paper, I have strived to provide a reconstruction of the practices and methods of documentation management at the museum through insight and analysis into the currently available museum documentation collections and archival records of the 
Ethnographic Museum and the professional literature concerning the history, organisation and the activity of the Museum. In addition to the previously mentioned, I have consulted the currently applicable laws and statutes concerning the museum activity and the references that deal with the position and defining of museum documentation through laws and statutes from the previous periods. ${ }^{1}$

The specific objective of this paper is to provide a historical overview and present the continuity of documentation management at the Ethnographic Museum, as well as to present the current activities and plans concerning the documentation and point out the role and the importance of museum documentation not only at the Ethnographic Museum, but in museums in general.

At the beginning of the text, I provided a concise overview of the notion of museum documentation through legislation in order to further emphasise the raised awareness about the importance of management of documentation both of museum and documentation collections since the foundation of the Ethnographic Museum. The forthcoming chapter presents the history of documentation management, as well as the work of the people who played the crucial role in the formation and management of the museum documentation. The final chapter provides a description of the current circumstances in the Documentation of the Ethnographic Museum and the methods and plans for the (re)systematisation of secondary documentation holdings, systematisation and processing of documentation collections, arrangement of primary documentation and work on tertiary documentation.

\section{MUSEUM DOCUMENTATION THROUGH NORMATIVE ACTS}

In practice both museum documentation and documentation collections have been in a subordinate position in relation to museum collections and they were included and defined through normative acts relatively late.

Efforts to regulate the museum activity by law in the former Yugoslavia started as early as during the first half of the $20^{\text {th }}$ century, only to intensify when the first laws about museums were passed in the individual republics of the former federation of states. Croatia saw the enactment of the first Museum Act in 1960 (OG 49/1960), which was amended in 1965 (Oklopčić 1990: 26). Simultaneously, in 1962, the Culture Council of the People's Republic of Croatia provided "Instructions on Methods of Book Keeping of Museum Collections and Card Catalogues in Museums and Museum Collections" (Šola ed. 1987: 7). The Museum Act passed in 1977 (OG 12/1977) did not define the form and the methods of management of museum documentation, yet in Article 11

1 Documentation management at the Ethnographic Museum was the topic of the written part of my state licence exam for the profession of Document Management Specialist in 2018, which in this text has been reformulated and enhanced with new insights. Considering the fact that I have been working at the Ethnographic Museum since the end of 2016 and it has only been this year that the process of (re)systematisation of the documentation holdings and documentation collections started, both the data and the results provided in this text are based on the insight into the documentation collections and archival records of the Museum that are currently only partially available due to the ongoing construction work on the museum building. I believe that the forthcoming systematisation and processing of the documentation collections will certainly provide new insights. 
it stated as follows: "Museum organisations are obligated to keep inventory records, books of records and card catalogues of objects in museum collections as prescribed by the Croatian Museum Council" (Šola ed. 1987: 7; Osrečki, 1990: 27). In 1989, the Croatian Museum Council provided "Instructions on the Basics for the Management of Documentation of the Objects in Museum Collections" that were intended to define and raise awareness among experts and encourage the process of creation of standardised and unique museum documentation. ${ }^{2}$

The basic provisions of the Museum Act (OG 142/1998) passed in 1998 include the notion of museum documentation and state that all the museum institutions are obligated to keep records about museum collections (Museum Act 1998, Article 7). It is important to highlight that museum documentation implies "information about museum objects that the experts need in order to be able to process them, as well as for identification, to determine their origin and the condition in which they were acquired and to gain insight into the condition of museum collections", while "the content and the method of management of museum documentation of museum collections have been prescribed by the Minister of Culture upon the proposal put forward by the Croatian Museum Council" (Museum Act 1998, Article 8). Through the provision included in Article 7 of the latter Act, museum documentation has been placed on an equal footing with museum collections in terms both of preservation and conservation.

The adoption of the "Ordinance on the Content and Method of Management of Museum Documentation of Museum Collections" (OG 108/2002) ensued, which was actually the first regulation to closely define the content, the forms and the methods of museum documentation management. This Ordinance divides the museum documentation into primary, secondary and tertiary. ${ }^{3}$ It defines it as a "systematically prepared, collected,

2 The CIDOC list (The Committee for the documentation of ICOM, International Council of Museums) of the minimum data categories for the description of museum objects was put forward in 1980 and was supposed to be applied at all national levels. Nevertheless, as soon as in 1981, a conclusion was reached at a CIDOC meeting that the proposed list needs to be extended by categories of data for individual disciplines (Šola ed. 1987: 8).

3 The museum documentation had been divided into primary, secondary and tertiary even before the adoption of the previously mentioned Ordinance. The museologist Ivo Maroević divided and explained documentation in accordance with the content and function. Primary documentation results from a direct contact with the objects, and the data about them are collected through "research, preservation and communication of heritage objects, they include the knowledge of them and all the types of events in them and around them or the events of which the object in question is the subject or the object" (Maroević 1993: 191). Consequently, according to Maroević, primary documentation also includes document collection items, such as maps and plans, photo archives, newspaper archives, sample collections, phonograph records library, film archives, video archives or slide archives. Secondary documentation includes the transfer of primary documentation to other media (microfilm, magnetic tapes or floppy disks). Tertiary documentation comprises of "revisions, card catalogues, catalogues, indexes, lists and all the other forms of revision of documentation" (Maroević 1993: 192-193). All the types of documentation are being redefined upon the introduction of modern technology and the development of museology. In accordance with the Ordinance on the Content and Method of Management of Museum Documentation of Museum Collections (OG 108/2002), primary documentation "includes the first and the largest set of data about museum collections. The obtained data result from record keeping, analysis and professional processing of objects. The primary documentation comprises of the inventory control register of museum objects, the catalogue of museum objects, museum object accession records, museum object deaccessioning records, the register of museum collection storage and the register of museum collection revision" (Ordinance 2002, Article 5). The secondary documentation "includes accompanying and supplementary holdings of museum activity. Secondary museum holdings may be organised in accordance with the presentation media and content. The secondary museum documentation comprises of the inventory control register of audio-visual holdings, the inventory control register of newspaper archives, the register of exhibitions, the register of conservation and restoration procedures, the register of educational activity, the register of professional and scientific papers, the register of publishing activities, documentation about marketing and public relations and 
organised and stored data sets, resulting from the course of the process of professional processing, protection and presentation of museum collections. It is based on agreed upon and determined number and quality of data about an object, a group of objects or an entire pool. Museum documentation is created during the process of keeping a collection inventory, cataloguing and indexing, all of which are a continuous process of upgrade and processing of data" (Ordinance 2002, Article 2).

"The purpose of managing museum documentation is to provide accurate information about museum collections, their condition, exhibitions, other events and activities of the museum, as well as about the history of the museum both from the professional and scientific aspect through clear and systematically processed holdings" (Ordinance 2002, Article 3).

Moreover, it is important to highlight also the "Ordinance about Professional and Technical Standards for Determining the Types of Museums, for their Work, as well as for Space for Museum Collections and Museum Documentation" (OG 30/2006), passed in 2006, which more closely defined the provisions concerning the preservation of museum documentation.

\section{DOCUMENTATION IN THE ORGANISATION OF THE ETHNOGRAPHIC MUSEUM IN ZAGREB}

The enactment of the "Rules of the Ethnographic Museum" was brought in 1961, which, among other things, also defined the internal organisation of the museum. ${ }^{4}$ At that point, the Museum was organised in four departments: the Department of General Affairs, the Professional and Scientific Department, the Professional Department and the Professional and Technical Department. What is currently considered as the Documentation of the Ethnographic Museum, in accordance with the division provided in the previously mentioned document, was included in the Department of Illustrative Scientific Material and Manuscripts (a part of the Professional and Scientific Department), ${ }^{5}$ Documentation Department (a part of the Professional Department) ${ }^{6}$ and

the documentation of the foundation and the history of the museum" (Ordinance 2002, Article 23). The tertiary documentation includes "tools in the form of different catalogues and indexes of objects, authors, as well as those in terms of chronology and topography and others congruent with the museum activity". It is generated "from the holdings of primary and secondary documentation in the form of thesauruses, indexes, catalogue cards and summaries and it is intended to enable a faster search and use of data from the existing documentation holdings" (Ordinance 2002, Article 38).

4 Stored in the Documentation of the Ethnographic Museum. Upon a more detailed insight into archival records during the future research it needs to be defined whether this is the first document that defines the organisation of the Museum or it had also been defined during the previous periods.

5 The Department of Illustrative Scientific Materials and Manuscripts included "drawings, graphics, oil paintings and other material intended for professional and scientific research, as well as valuable manuscript collections and all the fieldwork manuscript collections that regularly enter the museum; inventorying, cataloguing and scientific processing of the abovementioned collections" ((Rules of the Ethnographic Museum 1961).

6 The Documentation Department includes "identification, collection, arranging, keeping, inventorying, shelf marking, labelling and cataloguing of all the types of documentation for the history of the museum and the activities in connection with the museum and outside the museum, both in the past and currently, in co-operation with the archival services of the Department of General Affairs. The Documentation Service in co-operation with museum 
the Inventory and Depot Department - museum inventory and catalogue (a part of the Professional and Technical Department). ${ }^{7}$

In accordance with the internal organisation from the Statute of the Ethnographic Museum in Zagreb, dating back to the $14^{\text {th }}$ November 1966, and the Ordinance on Systematisation of Workplaces dating back to the previously mentioned year, document management jobs were included in the Inventory Section within the Inventory and Depot Department (a part of the Professional and Scientific Research Department) and Documentation Section within the Library and Documentation Department (a part of the Professional and Scientific Research Department). ${ }^{8}$ The Ordinance lists the following workplaces in connection with document management jobs: Document Management Specialist and Ethnographic Collection Inventory Management Specialist. ${ }^{9}$

The latter division was retained over the subsequent years in both the statutes and ordinances that prescribe the internal organisation of the Museum. In the Ordinance on Systematisation of Workplaces dating back to 1977 the Documentation was singled out as a unit within the Professional and Scientific Research Department and it com

collection managers takes care of completion of documentation required for the overall museum activities and primarily for the scientific research and cultural and educational activity of the museum and its collections and co-ordinates the systematisation of documentation of professional archives of individual departments" (Rules of the Ethnographic Museum 1961).

7 Inventory and Depot Department was only partly linked with documentation since it included "keeping and preservation of museum inventory records, keeping and preservation of catalogues and museum objects and care of material preservation of deposited museum collections, records keeping of object accession to and deaccession from the museum depot ...” (Rules of the Ethnographic Museum 1961).

8 The Inventory Section "includes the documentation of the museum collections, i.e. of each object in the museum collection that has been entered in inventory records and the corresponding card catalogue". In addition, in accordance with the Ordinance on Systematisation of Workplaces dating back to 1966 "it makes sure that each object that is accessioned into any collection is entered in inventory and recorded in corresponding registers and card catalogues. It keeps records of loans of museum inventory objects. The Documentation Section "comprises of records keeping of fieldwork documentation and manages 1 ) the archives (the professional archives of documented collections in accordance with the Ordinance on Systematisation of Workplaces 1966) and newspaper archives, 2) illustrative records, phonograph records library, film archives, photo archives or slide archives. (Statute of the Ethnographic Museum in Zagreb 1966., Ordinance on Systematisation of Workplaces 1966.). In the Statute of the Ethnographic Museum in Zagreb dating back to 1970, the Documentation Section, in addition to the previously mentioned work, it includes also "keeping abreast of publishing activity in the field of ethnology and related professions and acquisition of new materials; preparation of professional bibliography".

9 In accordance with the job description provided in the Ordinance for Document Management Specialist "in cooperation with experts and under their guidance, it keeps the inventory of the overall materials in the section: fieldwork records and other fieldwork documentation, photo material and all the types of imaging documentation material, as well as phonograph recordings and preparation for the depot; it enters new material into Object accession documentation; it keeps records about location and loans; it prepares the main and the special card catalogues in co-operation with experts; it does all the technical work in connection with records keeping and documentation (Ordinance on Systematisation of Workplaces 1966). The consolidated text of the Ordinance on Systematisation of Workplaces dating back to 1972 reads that the latter jobs included "pursuant to the provision in Article 3 of this Ordinance - curators, senior curators and experts in other scientific occupations".

In accordance with the job description in the Ordinance, the Ethnographic Collections Inventory Management Specialist "keeps records both of the available museum objects and on their acquisition; they manage the Main Inventory Control Register, Object accession and Object deaccessioning records and temporary inventory registers; they manage and arrange card catalogues in accordance with the Main Inventory Control Register, i.e. card catalogues by object, locality, sequence number; they keep records on loans of museum objects; they co-operate with collections managers and make sure the inventory is updated (Ordinance on Systematisation of Workplaces 1966). The Ordinance on Systematisation of Workplaces dating back to 1972 includes also "these jobs - pursuant to the provision in Article 3 of this Ordinance - curators, preparators and conservators - technicians."

Subsequently, the Ordinance on Systematisation of Workplaces and Work Tasks dating back to 1980 includes the jobs - document management specialist, museum expert and inventory specialist. 
prised of Museum Collections Inventory, Card Catalogue and Documentary Collection Archives. ${ }^{10}$ The latter division was retained in the Statute passed on the $5^{\text {th }}$ November 1987 in which Documentation is a separate unit.

In her paper dating back to 1989, Nada Gjetvaj stated that professional documentation comprised of Documentation of Museum Collections (inventory records, card catalogues, object accession records, object deaccessioning records), photo archives and illustrative records (Film Negatives Inventory Register, Photo Archives Inventory Register, Slide Archives Inventory Register, Inventory Register of Illustrative Collections, card catalogues) and Professional Archives (records on professional collections, card catalogues), which is similar to the current division of museum documentation (Gjetvaj 1989: 60-62).

Over the subsequent years, documentation was managed in a separate organisational unit, the Documentation Section, until 2005. Upon the Decision on amendments to the Statute of the Ethnographic Museum ${ }^{11}$ passed on the $4^{\text {th }}$ May 2005, documentation was a part of the Department of Collections and Documentation, as well as in accordance with the existing Ordinance on Internal Organisation and Operations of the Ethnographic Museum dating back to the $13^{\text {th }}$ June 2018 and the Statute of the Ethnographic Museum passed on the $13^{\text {th }}$ December 2018. In accordance with the previously mentioned legal acts, as well as in accordance with the Ordinance on the Content and Method of Museum Documentation Management, it includes work on primary documentation, secondary documentation holdings and tertiary documentation.

\section{DOCUMENTATION MANAGEMENT AT THE ETHNOGRAPHIC MUSEUM}

The documentation of the museum collections of the Ethnographic Museum has been kept since the foundation of the museum when around 20,000 of museum objects accessioned into the museum collections. Upon the decree on foundation of the Ethnographic Department of the Croatian National Museum in 1919, all the larger ethnographic collections of the Croatian National Museum in Zagreb were brought together. These fundamental museum collections resulted in the creation of the corresponding documentation or inventory records with shelf marks allocated in accordance with the source that the collection originated from (AH, UO, B, ŠM, BK). A joint inventory control register referred to as Ethnographica was introduced immediately upon the foundation of the museum in which fundamental collections were entered as the first five entries as independent units. ${ }^{12}$ Hence, the description of objects that accessioned

10 The Inventory of Museum Collections and Card Catalogue keeps the required records and card catalogues. It makes sure that each object that is accessioned into a collection is included in the inventory and entered in the required registers and card catalogues. The Archives of Documentation Collections manages the professional archives of fieldwork documentation collections, as well as the remaining manuscript collections. It takes care of photo archives, film archives, slide archives and other illustrative records (Gjetvaj 1989: 56-57).

11 Stored in the archives of the Ethnographic Museum in Zagreb.

12 Hence, the ethnographic collection of History and Archaeology Department of the National Museum in Zagreb has been entered under the number (Et) 1 - (AH) 1163 inventory number, (Et) 2 is the collection of folk craft 
into the museum collections through acquisition or donation was entered under the number six in the joint inventory control register. In the subsequent years several more inventory control registers with different shelf marks such as ZGZ, ES, Va, Ex, G and Arcana ${ }^{13}$ were introduced.

Simultaneously with the gathering of museum collections, documentation collections were gathered as well, thanks to Vladimir Tkalčić and Milovan Gavazzi or their intensive and systematic field research that started immediately after the foundation of the museum. ${ }^{14}$ The collections were gathered for the purpose of research, field recognition and exploration of ethnographic topics through the use of photography, film and phonograph recordings. "A wide range of interesting and valuable objects were collected (whether as gifts by individuals or through acquisition) during those both longer and shorter journeys, which have greatly enriched the museum collections gathered up to date. The collected information about folk life, as well as a large number of photographs and different drawings provided the foundations for the ethnographic archives of the museum." (Tkalčić 1922: 75) (Fig. 1)

In addition to a wide range of audio-visual collections, the Documentation of the Ethnographic Museum currently includes documentation concerning the history of the museum and museum activities - statutes, ordinances and other normative acts, logs, reports, correspondence, records, documentation in connection with field research and professional papers, newspaper archives, documentation of permanent and other exhibitions, as well as of publishing activity - catalogues, posters, invitations and magazines, to name a few. Until 2005, newspaper collections were gathered in the museum library and after that they were stored in the documentation where they continued being gathered. Nevertheless, no records were kept about them and they were not professionally processed. Their professional processing started in 2019. Posters in connection with exhibition activities in the Ethnographic Museum and in other

products "Berger Collection" - (B) 8183 inventory number, (Et) 3 collections from the Trade and Crafts Chamber in Zagreb - (BK) 1206 inventory number, (Et) 4 collection from the Croatian Museum of Teaching and Literary Union in Zagreb - (ŠM) 922 inventory number, (Et) 5 collection from the Museum of Arts and Crafts of the Royal National Craft School in Zagreb - (UO) 4503 inventory number (Gjetvaj 1989: 60; Zorić 2015: 54).

13 The book with the shelf mark ZGZ, was included in 1928. The objects acquired using the resources provided by the City of Zagreb were entered in that book until 1940. The shelf mark ES stood for Ethnological Seminar and it included objects that were partly owned by the Ethnographic Museum and partly by the Department of Ethnology of the Faculty of Humanities and Social Sciences of the University of Zagreb and they were used for teaching purposes. Varia included perishable objects and vulnerable objects. Exota - Ex was introduced in the 1970 's and it was intended for keeping inventory of objects of non-European origin from the collection of the History and Archaeology Department of the National Museum in Zagreb (AH). Nevertheless, that principle was not always consistently implemented and a proportion of it continued being managed in a joint inventory control register and a proportion in the register Ex. The register with the shelf mark $\mathrm{G}$ includes objects that entered the museum through intermediation or as a gift by the professor Gavazzi, yet before that they were inventoried in Ethnographica (in accordance with the information provided in the Inventory Control Register G, the objects entered the museum during the period from 1921 to 1937). The Inventory Register named Arcana includes only three inventory numbers for objects that are closely linked with intimate matters (kalafićur - a wooden statuette with a movable penis and two nakurnjak items - penis warmers) (Zorić 2015: 54).

14 Among significant explorations conducted during the first years of museum activities, it is important to highlight the Ethnographic Expedition in Pokuplje region dating back to 1923. (see Muraj, Aleksandra; Eckhel, Nerina; Zorić, Vesna: Memories from Pokuplje: Ethnographic Expedition 1923. Ethnographic Museum, Zagreb. 1993) Over the subsequent years, it is important to point out explorations of Zagreb outskirts (Resnik 1969, Čučerje 1974, Ščitarjevo 1975, Markuševec 1976, Šestine 1979). 
Croatian and international museums were also collected in the museum library. In 2017, exhibition posters in connection with the exhibition activity of the Ethnographic Museum were stored in the documentation.

A certain level of awareness about collecting, preserving, records keeping and professional processing of documentation collections has been present since the inception of the museum and at the start of its activity, yet it changed over the years and so did the collection policies. In fact, during the previous periods the documentation collections were not stored exclusively in the documentation and they are currently being preserved in several locations - the museum Secretary's Office, the Croatian State Archives ${ }^{15}$ and in the personal archives of museum staff members that have been gradually entering the museum documentation holdings as individual gifts or entire legacies. Given the extraordinary information value of the collections, we are currently striving to gradually, as much as possible, integrate, systematically arrange, process and digitise them and finally make them accessible.

Soon after the foundation of the Museum, at the end of the 1920's, in addition to the previously mentioned inventory control registers, museum object accession and deaccessioning records were introduced and the card catalogue with catalogue cards managed in accordance with the inventory number, object and the locality. Moreover, film negative inventory registers were introduced, photo archives, slide archives and illustrative collections, while records were kept of professional papers. ${ }^{16}$ Furthermore, card catalogue was also kept with catalogue cards for the photo archives, film negatives, slides (in accordance with the object and the locality) and professional papers (in accordance with the author, type of work and the locality).

Curators played the crucial role in the process of creation of the previously mentioned documentation. Hence, it is important to highlight the importance of the colleagues Tereza Paulić, Zdenka Sertić and Blaženka Szenczi, who through their work (drawings, sketches and outlines, among others) significantly enriched both the documentation and the documentation collections of the Ethnographic Museum from the visual aspect. (Fig. 2)

\section{MUSEUM PROFESSIONALS ACTING AS DOCUMENT MANAGEMENT SPECIALISTS}

At the start of the museum activity the museum professionals working during that period, more specifically Vladimir Tkalčić and Tereza Paulić, were in charge of maintaining and management of documentation on museum objects. In accordance with the currently available information, Tereza Paulić worked on the inventory and she continued maintaining and managing documentation after Tkalčić's departure in 1934

15 During the period from 1968 to 1990, the Ethnographic Museum several times handed over the documentation collections to the Croatian State Archives. http://arhinet.arhiv.hr/details.aspx?ItemId $=1 \_4443$ (visited on $10^{\text {th }}$ June 2019).

16 Records were kept of professional papers from 1972 to 2005. The remaining documentation collections were gathered and only partly systematically arranged and listed. 
(Gjetvaj 1989: 51; Mokos 2011: 13). During the subsequent period it is important to highlight the role of Paola Gabrić, who tackled the issues in the management of the documentation of museum objects and Blaženka Szenczi, who kept the inventory and catalogued a large number of objects during the period from 1941 to 1975 (Mokos 2011: 19, 24). After the refurbishment of the museum in 1972, the management of documentation was taken over by Nada Gjetvaj until her retirement in 1995 (Ibid.: 27-28). In addition to Nada Gjetvaj, other members of museum staff were involved in documentation management, such as Ivanka Ivkanec (during the period from 1973 to 1976) and Emilija Rona (inventory specialist during the period from 1974 to 1994) (Ibid.: 33). Jasna Mokos was employed as inventory specialist and subsequently also as document management specialist from 1995 to 2016 (Ibid.: 35). From the end of 2016, document management specialist and also the author of this text took over the work of documentation management.

In addition to the previously mentioned colleagues, audio-visual collections were managed also by Marcel Davila (during the period from 1942 to 1969), Nada Gjetvaj (from 1972 to 1995), Mladen Tomljenović (from 1995 to 2013) and Matija Dronjić, who took over the management of Audio-Visual holdings in 2013 (Ibid.: 18, 27-28, 18, 27-28, 42). ${ }^{17}$

As is evident from this brief overview, curators and individual museum professionals were in charge of work in connection with management and organisation of documentation and they simultaneously also collected and only partly processed and recorded documentation collections. In the process of laying of the foundations and in the development of museum documentation it is important to emphasise the contribution of several crucial people. Consequently, I am hereinafter only referring to them to provide an incentive for a more comprehensive research that certainly needs to be performed in order to gain a deeper insight and a clearer idea of their work, role, importance and contribution in the context of documentation management, both at the Ethnographic Museum and beyond.

Vladimir Tkalčić (1883 - 1971) was the first curator of the Ethnographic Museum, in which he worked from 1919 to 1934 . He strived to both systematically and in a high-quality way process the objects that entered the museum collections upon its foundation. It was primarily thanks to him that the foundations were laid for both the professional and scientific work upon the start of the museum activity, since he created the first collections of museum objects, launched the inventorying of the collections and

17 The references that address the issue of modus operandi and the history of museum documentation at the Ethnographic Museum in Zagreb do not provide a comprehensive insight into the work linked with the functioning and documentation management at the Museum. Neither do they provide a clear overview of the museum staff members who were involved in the work in connection with the documentation. The information provided in the references primarily concerns the practice and methodology of work on documentation. Since inventory control registers do not include the information about the responsibility for the entries and the list of people in charge of work on documentation was only partially provided on cards, I strived to reconstruct it using the currently available references, as well as archival records and documentation holdings. The catalogue of the exhibition entitled the Employees of the Ethnographic Museum in Zagreb (2009), by the author Jasna Mokos, provided me with the information about work on documentation in the form of hints about work done by individual colleagues. Nevertheless, it is primarily due to some gaps in the form of a lack of information between specific periods and insufficiently specified duties, further research needs to be performed primarily of the museum archives, for a more detailed analysis, which I leave for future elaboration and I am hereby providing only a brief overview of the issue. 
established the documentation holdings (Zorić 2015: 53). Hence, immediately upon the museum foundation he introduced the inventory control register, both the main and the supplementary card catalogues, as well as object accession and deaccessioning records. He introduced inventory control registers and card catalogues alsofor documentation holdings (photo-archives, film negatives, slides and illustrative collections).

Paula Gabrić (1909 - 1989) was a curator at the Ethnographic Museum from 1948 to 1978. She was the Head of the former Section of Basic Crafts and Handicrafts, within which she managed the collection of objects for the processing of wood, straw, metal, leather, fur and stone. Within the Section of Traditional National Costumes, she managed the collection of the traditional costumes of the north-western part of the Pannonian Croatia (Moslavina, Posavina, Pokuplje and Podravina region). Hence, in addition to her work on collections, she also performed a comprehensive situation analysis in terms of inventorying and cataloguing of museum collections in both the national and international museums and proposed solutions to problems with the management of the documentation of ethnographic collections. ${ }^{18}$ During the proposal preparation she complied with the compulsory collections management system in the museums of the former Yugoslavia provided by the Federal Ministry of Science and Culture in 1950 (Gabrić 1954: 31). She presented the methodological frameworks in the management of documentation of museum collections in her work entitled "The Catalogue of the Ethnographic Museum: Inventorying of Museum Objects and the Inventory Register System and Cataloguing with a Particular Emphasis on the Specific Features of the Ethnographic Profession" dating back to 1954. In her paper, she presented a proposal of the new method of professional processing of collections through detailed instructions in terms of allocation of inventory numbers, dimensions and the matter of the main inventory register, the appearance and the content of a catalogue card, inventory wrappings, handy card catalogues, as well as a proposal of groups for the object catalogue (Gabrić 1954.; Zorić 2015: 55). It is important to highlight the fact that the colleague Gabrić kept abreast of what at the time were trends in museology. In fact, the importance and the significance of quality professional processing of objects became the topic of intense discussion at the international level in the mid- $20^{\text {th }}$ century. In those years, the museologist Antun Bauer was also very actual with his reflections on the previously mentioned topic. Hence, he published a text in the magazine Muzeologija ("Museology"). The latter text was entitled "Some Remarks on Professional Inventorying in Museums". In the latter text, he pointed out that "professional conducting and maintaining of inventory control of museum material is perhaps the most neglected segment of work in our museums" (Bauer 1956: 16). He stated that was because of a lack of "a clear and specified system of professional museum inventory due to which most museum professionals shirk such work" (Ibid.: 16). Moreover, he stressed the Ethnographic Museum or the work by Paula Gabrić as a good role model, pointing out as follows:

18 The museum archives include a wide range of documents that confirm the ample correspondence with the distinguished ethnologists and museum experts at the European level, such as Claude Lévi-Strauss, Georges Henri Riviére or Andreas Lommel, which provide information about their methods of inventorying and cataloguing (Zorić 2015: 55). 
"The paper by the colleague, the professor Paula Gabrić, a curator at the Ethnographic Museum in Zagreb, is certainly the most thoroughly studied paper, as it provides a solution to the problems in conducting and maintaining of inventory of the ethnographic collection. It resulted in the fact that the museums in Djakovo and Osijek introduced this inventory system for ethnographic objects in their collections. These are most probably the best arranged museum inventories in our museums" (Ibid.: 20).

Solution proposals that she came up with at the Ethnographic Museum were only partially accepted and in the 1960's, starting from the inventory number 19,001, new sections in the inventory control register were introduced, as well as in the catalogue card whose appearance had been changed. ${ }^{19}$

Nada Gjetvaj (1930) was a curator at the Ethnographic Museum from 1955 to 1995 and, in addition to her work on museum collections, she was also in charge of documentation management. She continued pursuing the previously implemented practices in the management of the documentation of museum objects. In 1972, she introduced records keeping of Professional Document Collections (fieldwork reports, fieldwork records, questionnaires and similar documents) and of the handy card catalogue. In her master's thesis entitled "A Comprehensive Description and Perspective Development of the Ethnographic Museum in Zagreb" that she defended in 1981 and adapted for publication in the journal Ethnological Researches in 1989, entitled "The Ethnographic Museum in Zagreb - on the Occasion of the $70^{\text {th }}$ Anniversary", she provided a systematic overview of history, organisation and activities of the museum. This text is extremely helpful for systematisation of documentation holdings and it is a source of a wide range of information during the professional processing of documentation collections stored in the museum documentation, concerning which there are no lists, records and information or they are very scarce (exhibition activity, professional and scientific papers and field research documentation, among others).

The work of the colleague Gjetvaj provides a bond of great assistance in the forthcoming stage of work on the documentation of the Ethnographic Museum that has been indicated hereinafter. During that process, there are plans to connect and organise the current condition and the structure of documentation collections of the Ethnographic Museum in accordance with the practices and holdings that had been established immediately upon the foundation of the museum, yet keeping in mind the contemporary museological practices and the legal framework.

19 Sections in the inventory control register: inventory number /category of monuments of value/ number of the object accession register / collection, section/ description / author, producer/ time of origin / material, technique / size, weight/ number of items / condition, conservation interventions/ provenience: place of production, place of use, place of finding/ method of procurement, date, file no./ name and address of the seller or the donor / price / photo, slide / inventory wrapping / location/ remark. A catalogue card includes the following information: inventory number/ collection; group; sub-group/ name of the museum / locality / standardised name / name in the dialect / time of origin / locality of production / whether it is an original, a reproduction, a copy / when and how it accessioned the museum / material / technique / ornament / condition / description / number of items / dimensions / weight / basic function / purchase price / category of value / location shelf mark / photo archives shelf mark / inventory wrapping / note / description - additional / references / restoration interventions / inventoried by. 


\section{THE DOCUMENTATION AT PRESENT}

The documentation of the Ethnographic Museum in Zagreb is currently managed in accordance with applicable laws, primarily with the Museums Act (OG 61/2018) and the Ordinance on the Content and the Methods of Management of Documentation of Museum Collections (OG 108/2002). The work on documentation and documentation collections is currently undergoing the reorganisation process, which primarily refers to the management of secondary documentation holdings in an effort to fully harmonise the practices with applicable laws. Nevertheless, we are striving to act in accordance with the previously implemented practices and the traditions, since the foundations for documentation management at the Ethnographic Museum have been laid before the provision of the legal framework and the regulations. In accordance with the Ordinance on the Content and the Methods of Management of Documentation of Museum Collections (OG 108/2002), the museum documentation is divided into primary, secondary and tertiary and I am hereinafter providing an overview of the current situation in the Documentation of the Ethnographic Museum based on the previously mentioned division.

The primary documentation of the Ethnographic Museum is managed using the software for the processing of museum collections $\mathrm{M}++$. It comprises of the inventory control register, the catalogues, the registers of object accession and deaccessioning and the storage register. In accordance with the Ordinance on the Content and the Methods of Management of Documentation of Museum Collections (OG108/2002), the primary documentation comprises also of records on revision of museum collections. ${ }^{20}$ The first official revision of the overall collections was made in 2016 and a total of 45 revision logs of collections with accompanying documentation were entered and stored among the documentation. During the ongoing arrangement and systematisation of documentation collections, the logs about handover and delivery or revisions of individual collections that were stored in the Documentation over the years have been added to the previously mentioned logs. The preparation of the inventory control register for the printout of revision lists from the base is currently the priority of the work on the primary documentation in order to ensure a unified approach that will enable a higher quality in terms of revision analysis performance, while striving to achieve the balance and reconcile the status between the collections and the overall museum holdings.

The secondary documentation is managed in the relational database $\mathrm{S}++{ }^{21}$ As previously mentioned, before digital processing, inventory control registers were managed for audio-visual collections, while the remaining documentation collections were

20 The inventory control register of museum objects was introduced upon the foundation of the museum, while the card catalogue and the Object Accession and Object Deaccessioning Register were introduced not long after that. Museum storage is managed through lists of records of objects that were compiled upon the items accessioning into the museum. Since the transition to collections management software all the previously mentioned documentation forms have been managed digitally $(\mathrm{M}++)$.

21 Audio-visual holdings in S + + have been managed since the introduction of the software in 2009, as opposed to documentation holdings that have been managed since 2017. 
gathered and stored in the documentation, without detailed lists, records or inventory control registers. Consequently, the work on documentation collections is currently passing the stage of analysis of its structure through the content and the type of the collections, which will be followed by the processes of systematisation into units, the corresponding documentation holdings and professional processing. Through the insight gained thus far the collections gathered in documentation were those concerning museum objects, museum activity and the professional work of museum staff, as well as different letters, reports, logs, normative acts and other similar collections. The idea behind the systematisation of the existing documentation collections was to respect the policy of gathering of documentation collections and the continuity of documentation management at the Ethnographic Museum, in accordance with applicable laws. The systematised documentation collections will be managed through holdings of newspaper archives, exhibitions, publishing activity, professional and scientific work, educational activity, events, conservation and restoration interventions, the documents about the founding and the history of the museum and the professional archives.

The tertiary documentation in the form of catalogue cards was introduced during the first years of museum activity thanks primarily to Vladimir Tkalčić and Milovan Gavazzi who had recognised the need for the implementation of a data management system. ${ }^{22}$ The existing system of processing of museum collections and documentation in digital form managed tertiary documentation through a control of terms, which is achieved through the use of controlled dictionaries and thesauruses, in an effort to improve both the accessibility and the quality of the search. Having realised the importance of the work on the tertiary documentation, the Ethnographic Museum became involved in the work on an addition in 1990, while in 2006 a project of preparation and development of the terms was launched through the central system or a thesaurus for ethnographic museum objects at the level of the Republic of Croatia. ${ }^{23}$

\section{THE DIGITISATION PROCESS}

New technologies were introduced to museums in an effort to harmonise and standardise the approach to processing of objects irrespective of the differences and the specific features of individual professions in order to improve and increase the accessibility of the collections. The digitisation is a process that the Ethnographic Museum saw simultaneously with the digitisation of museum activity in Croatia at the beginning of the 1990's within the project entitled MUGIS (Museum and Galleries Information System) through which the Museum Documentation Centre (MDC) provided the Museum Data Object Entry System (MODES) software (Zorić 2002: 315). In the mid-1990's, the

22 In addition to the main card catalogue of the museum collections arranged in accordance with the inventory number, the Documentation also includes supplementary card catalogues in accordance with the type of object and the locality. For documentation holdings there is a card catalogue of negatives in accrodance with the type of object and the locality and the Professional Archives in accordance with the author, type of item and the locality.

23 A proposal for an addendum to the classification of museum objects for the field of ethnography was prepared by the working group of the Ethnographic Museum comprising of M. Randić Barlek, I. Šestan, A. Brenko and N. Eckhel. (Fruk 1990: 25) I. Kolbas and A. Vlatković worked on the thesaurus during the period from 2006 to 2012 , when the work was interrupted for several reasons. 
Ethnographic Museum, in co-operation with the IT company Microlab, developed a software for digital processing of data on museum objects named Promus (Ibid.: 316). Starting from 2009, the Museum introduced the software for digital management of museum documentation $\mathrm{M}++{ }^{24}$ that has been additionally adapted in terms of the specific features of the profession (Zorić 2015: 56). From its introduction to the present day, the software has been continuously developing through co-operation between the museum, information and IT specialists, keeping abreast of the standards and methods both of the modern museology and individual professions, as well as the technological development. We are currently undergoing the transition to and the development of the web app Modulor.$++^{25}$ The Ethnographic Museum was provided the opportunity to use Modulor ++ in the mid-2017 and a proportion of the curators started using this software.

The specific objective of the digitisation process is to conserve and protect the museum collections and the documentation, as well as to simultaneously provide a deeper insight, facilitate the search and the accessibility of data or heritage, both for the professionals and the wider user community. The Ethnographic Museum is striving to meet the latter objectives through the projects implemented thus far, as well as those that are currently only being prepared. During the previous years, the Perinic Collection and the Collection of Traditional African Art by Drago Muvrin have been fully digitised and accessible to the public. The same applies to the Collection of Non-European Cultures that has been digitised through the project "The Explorations by the Seljan Brothers" and a section of the Musical Instrument Collection through the project entitled "With the Croatian Traditional Musical Heritage into the World". The digitisation of a section of photo archives is also underway, through a pilot project entitled "The Ethnographic Museum Online". Moreover, a section of documentation holdings, such as the glass negatives and manuscript collections, has been digitised with the previously mentioned section of the photo archives, yet it is currently inaccessible to the public.

\section{INSTEAD OF A CONCLUSION}

Against the backdrop of the technological development, as well as the contemporary museology and applicable legal framework, the role played by both the documentation and the document management specialist in museums have changed. One of the objectives of documenting is the use of documentation (Maroević 1993: 194), while museum documentation currently increasingly implies communication with different groups of users, ranging from members of the museum staff, colleagues, professionals of different profiles, students to the wider user community both in the real and virtual space. As pointed out by the colleague Matija Dronjić, during his presentation at the professional

24 The museum collections are managed in the module for the management of primary documentation $\mathrm{M}++$, while the items in the documentation holdings are managed in a relational database $\mathrm{S}++$.

25 Modulor ++ "ensures an integrated approach to the databases $\mathrm{M}++, \mathrm{S}++, \mathrm{K}++$ through any web browser. The deployment of the app in the cloud is supported, which enables web accessibility or the introduction of the app on the local web of the institution..." (Zlodi 2016: 253-254). 
and science seminar entitled Digital Humanities, ${ }^{26}$ the Ethnographic Museum "has seen a long-term continuity of creative use of museum documentation" through projects of digitisation, printed catalogues, exhibition projects, as well as through the web of the Museum where the secondary documentation is also partly visible and accessible through exhibitions, special events and the publishing activity.

During the first 100 years of activity of the Ethnographic Museum, as well as in the broader context of museum theories, legal frameworks and museum practices that have been presented in the text, it is evident that the role of the museum Document Management Specialist greatly exceeds the previously done work linked primarily with the copying of information. The Document Management Specialist at the Ethnographic Museum in Zagreb currently, in addition to the management of secondary documentation holdings and the processing of documentation collections, plays an increasingly important role in the processes linked primarily with communication and the use of documentation by different user groups. The latter primarily applies to standardisation and arrangement of (meta) data, since only the qualitatively prepared documentation has the potential and the possibility to be used in modern technologies, or in virtual reality where most of the communication currently occurs.

\section{REFERENCES}

BAUER, Antun. 1956. "Neke primjedbe na stručno inventiranje u muzejima”. Muzeologija 5: 16-27.

GABRIĆ, Paula. 1954. "Katalog Etnografskog muzeja: Inventiranje muzejskih predmeta i sistem inventarnih knjiga te katalogiziranje s naročitim osvrtom na specifičnosti etnografske struke". Muzeologija 4: 3-66.

GJETVAJ, Nada. 1989. “Etnografski muzej u Zagrebu - u povodu 70. obljetnice”. Etnološka istraživanja 5.

FRUK, Marinka. 1990. "Informacija o radu Radne grupe za klasifikaciju muzejskih i galerijskih predmeta i dopuna klasifikacije za grupu Umjetnički predmeti i komunikacija i simbol te etnografska građa”. Bulletin o informatizaciji muzejske djelatnosti SR Hrvatske 2: 22-36.

MAROEVIĆ, Ivo. 1993. Uvod u muzeologiju. Zagreb: Zavod za informacijske studije Odsjeka za informacijske znanosti, Filozofski fakultet Sveučilišta u Zagrebu.

MOKOS, Jasna. 2011. "Dokumentacija Etnografskog muzeja u Zagrebu”. Etnološka istraživanja 16: $273-276$.

MURAJ, Aleksandra, ECKHEL, Nerina i Vesna ZORIĆ. 1993. Pokupska sjećanja: Etnografska ekspedicija 1923. Zagreb: Etnografski muzej.

OKLOPČIĆ, Jagoda. 1990. "Muzejski zakoni i zaštita muzejske građe”. Informatica museologica 21/3-4: 26-27.

OSREČKI, Dubravka. 1990. "Dokumentacija kao oblik zaštite muzejskog fundusa”. Informatica museologica. 21/3-4: 27-28.

26 Held at the Ethnographic Museum, Zagreb, the $1^{\text {st }}$ June 2017, organized by the Croatian Ethnological Society. 
Pravila Etnografskog muzeja, 1961., Dokumentacija EMZ.

Pravilnik o sadržaju i načinu vođenja muzejske dokumentacije o muzejskoj građi (NN 108/2002).

Pravilnik o sistematizaciji radnih mjesta, 1977., Dokumentacija EMZ.

Pravilnik o stručnim i tehničkim standardima za određivanje vrste muzeja, za njihov rad, te za smještaj muzejske građe i muzejske dokumentacije (NN 30/2006).

s.n. 1989. "Upute o osnovama za vođenje dokumentacije o predmetima". Informatica museologica 19/3-4: 144-147.

Statut Etnografskog muzeja u Zagrebu, 1966., Dokumentacija EMZ.

Statut Etnografskog muzeja u Zagrebu, 1987., Dokumentacija EMZ.

Statut Etnografskog muzeja u Zagrebu, 2018., Dokumentacija EMZ.

ŠOLA, Tomislav, ur. 1987. "Dokumentacija i klasifikacija muzejskih i galerijskih predmeta”. Muzeologija 25: 3-117.

TKALČIĆ, Vladimir. 1922. “Etnografski muzej u Zagrebu”. Narodna starina 1: 73-75.

Zakon o muzejima (NN 142/1998, NN 110/2015, NN61/2018).

Zakon o muzejskoj djelatnosti (NN 49/1960, NN 12/1977).

ZLODI, Goran. 2016. "Uloga Muzejskog dokumentacijskog centra u informatizaciji i digitalnoj transformaciji muzeja u Hrvatskoj”. Muzeologija 53: 234-262.

ZORIĆ, Vesna. 2002. "Iskustva u primjeni računalnog programa Promus u dokumentaciji zbirki Etnografskog muzeja u Zagrebu”. Etnološka istraživanja 8: 315-320.

ZORIĆ, Vesna. 2015. "Stručna obrada građe i registracija zbirki Etnografskog muzeja u Zagrebu”. Etnološka istraživanja 20: 53-59.

www.emz.hr (visited on $3^{\text {th }}$ June 2019).

http://arhinet.arhiv.hr/details.aspx?ItemId=1_4443 (visited on $10^{\text {th }}$ June 2019). 